\title{
膵島の機能性 $\beta$-細胞腺腫の光顕および電顕的観察
}

\author{
小島原将保 \\ (財竹田綜合病院病理（会津若松市) (院長：菊地良郎博士） \\ （昭和57年12月17日 受付）
}

\section{は じめに}

ヒト膵臓の Langerhans 島細胞腫の症例報告は多 く, この中には, 電顕的な研究も含まれている ${ }^{1) ~ 9)}$. 今回, 膵島の機能性 $\beta$-細胞腺腫 (functioning $\beta$-cell adenoma) の手術例と, 剖検により, 膵に腺腫が発 見されたが, その脳の病変から, 同じく機能性の $\beta$ 細胞腺腫と思われた 2 症例について, 光顕的, 電顕 的に観察することができたので報告する.

\section{症例}

症例 1 (手術例)。 50歳, 女性 (農業). 10年前か ら, 空腹時に発汗と目の前が暗くなることに気づい ていたが，自然に回復していた。 8 か月前から，意 識消失を伴う発作が, 空腹時や, 農作業中にもしば しば出現するようになった。検査の結果, 空腹時血 糖值は $19 \mathrm{mg} / \mathrm{dl}$ 以下, また, 血清免疫反応性インス リンテスト (IRI) は $36 \mu \mathrm{u} / \mathrm{ml}$ をしたので, 膵島細 胞腫 (insulinoma) が疑われた。開腹したところ, 膵 尾部に直径 $1 \mathrm{~cm}$ のほほ球形で境界鮮明な兏白色腫 瘤が認められたので, 周囲の健常組織をも含めて切 除された (病理組織学的診断： $\beta$-cell adenoma). 術 後, 血糖値は正常となった。

症例 2 (剖検例)。56歳, 女性 (農業)。死亡する 4 年前から, 意識消失を伴う発作があり, 発作前に は眠くなるのに気づいていた。CT 上, 脳に萎縮が あり, Creutzfeldt-Jacob 病が疑われた。最後の発作 に引き続いて， 1 年 6 か月の長いあいだ，一度も目 覚めることがなく, 肺炎と尿路感染症を合併して死 亡した。剖検の結果は, 膵尾部に $2.0 \times 1.2 \times 1.0 \mathrm{~cm}$ の境界鮮明, 孤立性の死白色腫瘤が発見された（病 理組織学的診断: $\beta$-cell adenoma with psammoma body).脳では, 皮質の軟化を伴った前 頭葉の萎縮（重量：990g）が認められたが, 病理組
織学的には, Creutzfeldt-Jacob 病の所見はなく, 低 血糖に基因した脳症 (hypoxic encephalopathy due to hypoglycemia) であった. 副腎や脳下垂体には著 変を認めない. なお, 入院中, 患者の血糖值が 1 度 だけ測定されたが $(99 \mathrm{mg} / \mathrm{dl})$, IRI は検査されな かった.

\section{検 索 方 法}

光顕用標本は, ホルマリンに固定, パラフィンに 包埋し, hematoxylin-eosin 染色, Mallory の膠原 線維染色, aldehyde-fuchsin 染色, 鍍銀染色などを 施した。

電顕的検索には，ホルマリンに固定した組織を細 片し, $5 \%$ glutaraldehyde と $2 \%$ オスミウム酸に再 固定した. 試料は, アルコールで脱水の後, Eponに 包埋した。超薄切片は LKB-Ultrotome III で作製 し，酢酸ウランと鉛で二重染色を施し，JEM-100S (JEOL) で観察した.

\section{観 察 結 果}

腫瘍の肉眼的所見 症例 1 と 2 の脺尾部の腫瘤 は, 周囲の膵組織とは明瞭に境界されていた(図 1).

光学顕微鏡的所見 腫瘍組織と膵組織の間には, 薄い結合組織が存在している。腫瘍細胞は, 類円形 核を有した多角形の細胞で, 毛細血管に囲まれ, 充 実性胞巣状ないし索状に配列, 場所によっては小腔 を囲んでいる(図 $2 \mathrm{a}, \mathrm{b}$ )。症例 2 では, 腫瘍細胞 間に砂粒体 (psammoma body) が散見された（図 2 b ).

電子顕微鏡的所見 腫瘍付近の膵島細胞は， 2 症 例共, 正常ヒトで観察されている所見と同様であっ た ${ }^{10) 11)}$.

腫瘍組織を弱拡大で観察すると, 細胞塊は毛細血 管を含む少量の結合組織で包まれている(図 3 ), 腫 瘍細胞には, 細胞質が比較的吸るい吸調細胞と, や 


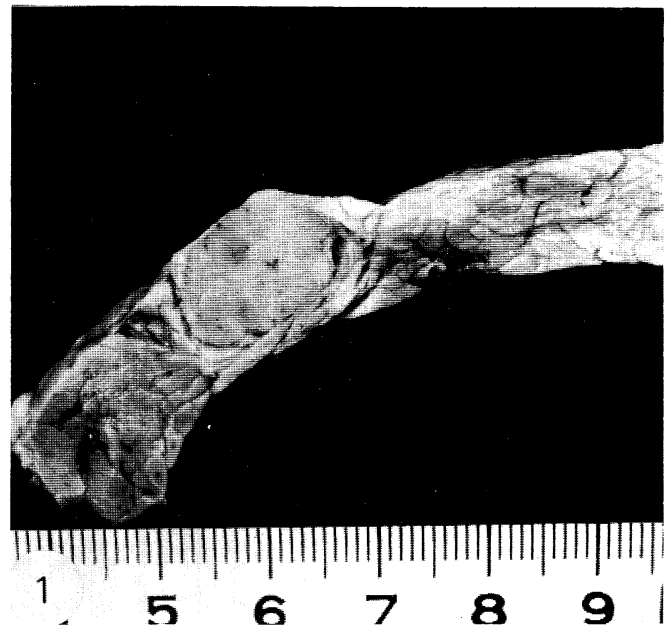

図 1 膵尾部の腫瘤（症例 2)

や胞体の暗い暗調細胞とが区別される（図 3，4）。 前者には，分泌顆粒が豊富であるが，後者に含まれ ている分泌顆粒の数は, 少ないものから豊富なもの までさまざまである。一般に, 分泌顆粒の電子密度 は高い. 腫瘍細胞間には, 接着斑 (desmosome) がみ られた。

腫瘍細胞の糸粒体は, 比較的多く, 類円形, とき に桿状構造を示し, その櫛 (crista) はほぼ平行に配

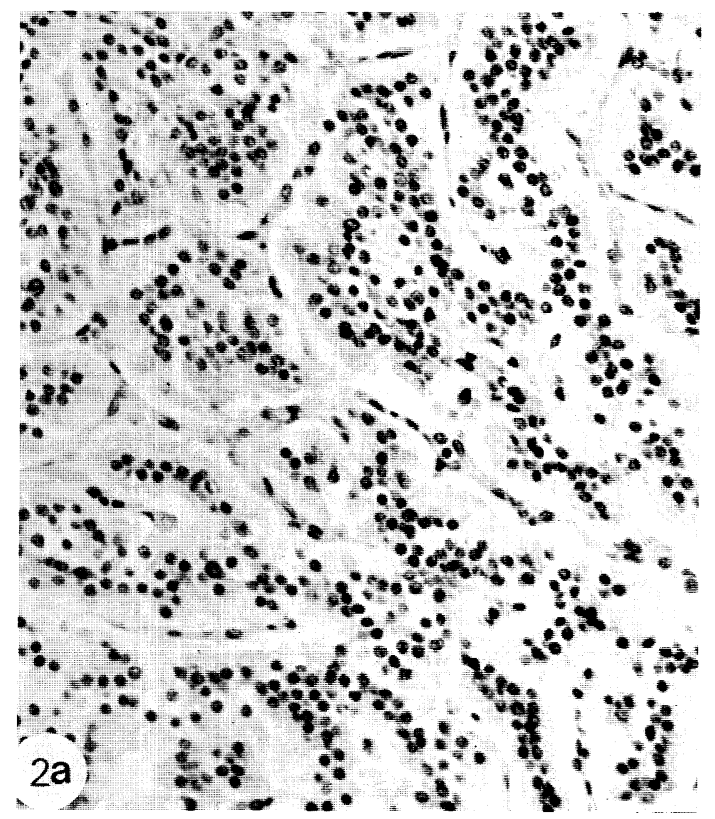

列している。しばしば脂質小体 (lipoidal body) がみ られたが, その内部には, 多房性の小胞や空胞がつ まった状態，つまり polyvesicular lipoidal body の 形であった（図 5 )。粗面小胞体 (rER) は，層板状 に配列していることが多いが，一般に小さい。さま ざまな大きさの lysosome $(1.5 \sim 3 \mu \mathrm{m})$ が存在して いたが，これらに極めて酷识した糸粒体も認められ た（図 7 )。核の周囲や細胞質の一部には, 直径約 $100 \AA$ の filament の束が諸志向に走り，あるいは系 まり状にかたまって存在していた(図 6 ). その中に は, しばしば，分泌顆粒が認められた(図 6 )。症例 1 の腫瘍細胞内に, ribosome lamella complex が 存在していた（図 8 ).

分泌顆粒。 $\beta$-cell adenomaにみられた分泌顆粒 の数はさまざまである。顆粒の大きさは，扔扔よそ $300 \sim 500 \mathrm{~m} \mu て ゙$, その外側は一層の膜で覆われてい る. 顆粒の形は, 円形ないし楕円形で，その中に電 子密度の高い芯 (core) を入れ,ている。この芯の形は さまざまで，球状，板状，針状などで，それぞれの 形のものを数個づつ入れて core を形成しているの もある(図 4-7)。つまり，腫瘍細胞の顆粒は，七 卜膵島の $\beta$ 一細胞の顆粒に酷似していた。また, 顆粒 には, 低電子密度の均質性の, 芯, 殆んど芯を入れて いないものなどがあり, 分泌顆粒の膜の断裂や一部

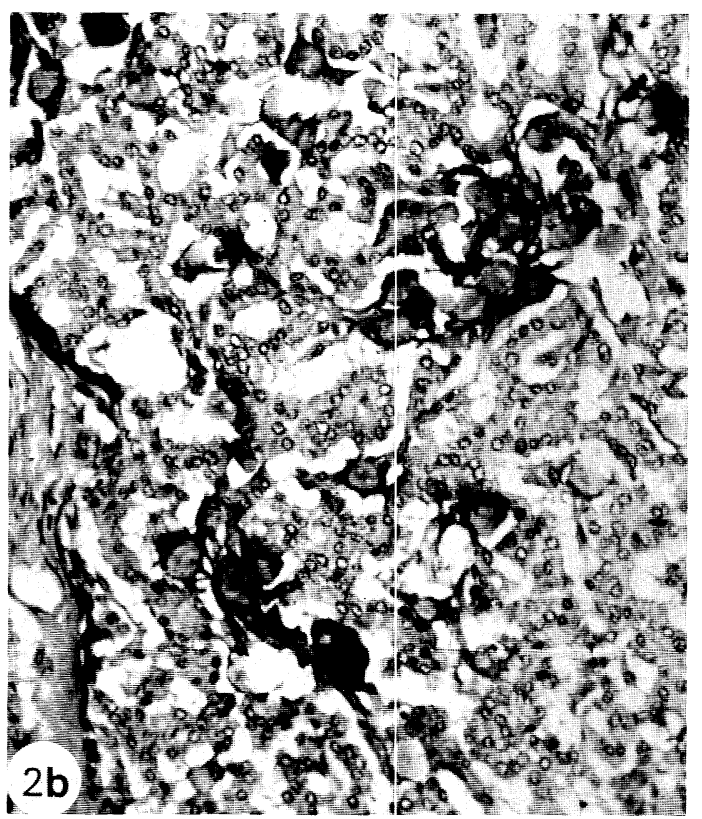

図2病理組織学的所見. (a)症例 1, (b)症例 2 . 


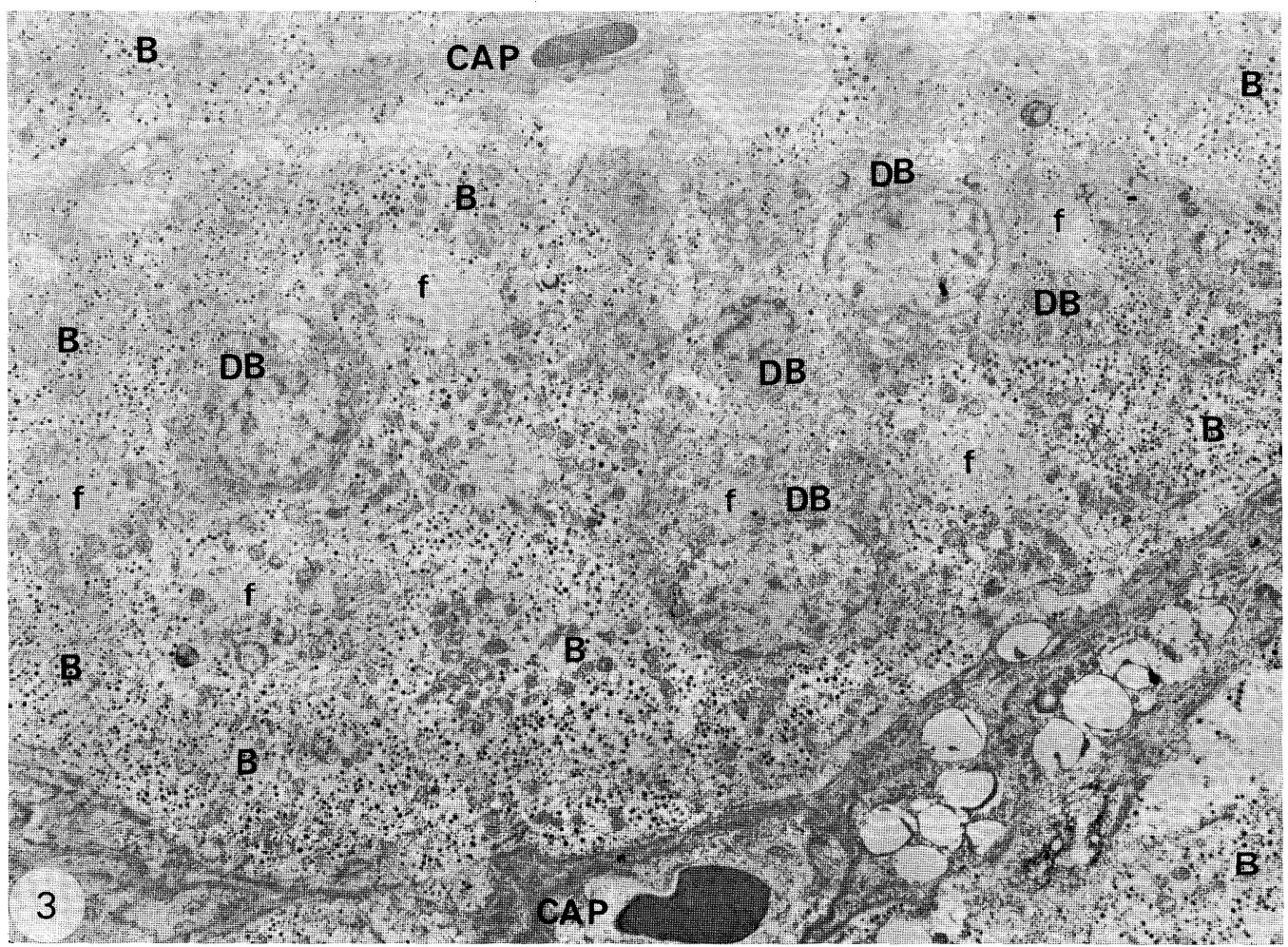

図 3 膵島 $\beta$-細胞腺腫の弱拡大電顕写真. $\times 2,000$.

図 $3 \sim$ 図10は症例 1 , 図11は症例 2 の電顕写真.

略語 : $\mathrm{B}$, 明調 $\beta$-細胞; $\mathrm{DB}$, 暗調 $\beta$-細胞 ; $\mathrm{f}$, 細胞質内 filament ; CAP, 毛細血

管; $\mathrm{ER}$, 粗面小胞体; $\mathrm{D}$, dense body; $\mathrm{L}$, 脂質小体; $\mathrm{E}$, 内皮細胞; $\mathrm{BM}$, 基底膜.

消失したものなども認められた（図 9，11）。

腫瘍組織内にみられた毛細血管は, 有空性 (fenestrated capillary) で，その基底膜は連続して認めら れた。しばしば，毛細血管側の腫咟細胞の膜に沿つ て，分泌顆粒が集簇して，または並んでみられた。 また，血管腔内に，分泌顆粒類似の構造物が存在し ていた（図10）。

症例 2 にみられた砂粒体は，ほぼ類円形で，その 超微形態は表層に中等度電子密度の層と, 深部には 電子密度の高い針状結晶様構造物が密に配列してい た(図11)。

\section{考察}

ヒト膵臟の Langerhans 島細胞には, $\alpha, \beta, \delta の$ 各細胞があり，これらの細胞が集って 1 個の萃島を 形成している10111).
膵島由来の腫瘍は, インスリンの過剩分泌を示し, $\beta$-細胞由来の機能性膵島腫瘍と, ホルモン分泌を示 さない非機能性の膵島腫瘍とが知られている ${ }^{12) 13)}$. 症例 1 は, 明らかに前者に属する。症例 2 は, 膵島 腫瘍と診断するのに必要な検査がなされていない が, 臨床経過, 脳の病理組織学的所見, および分泌 顆粒の形態から，やはり機能性の腫瘍と思われた。

腫瘍細胞の分泌顆粒. Islet cell tumor における $\beta$-顆粒は, 非腫瘍性 $\beta$-顆粒よりも多彩であること ${ }^{3)}$, 過インスリン血症を伴った $\beta$-cell adenomaにおい ては, 顆粒は $\alpha$-顆粒類似でインスリンの末分化顆粒 または変化したものであること4)，また顆粒に 2 種 類みられること鼻などの報告がなされている。今回 観察した 2 症例の腫瘍細胞に認められた分泌顆粒の core (芯) は，原則的には crystalloid で，顆粒膜と 芯との間にはすきまがあり，芯の切れた面により多 


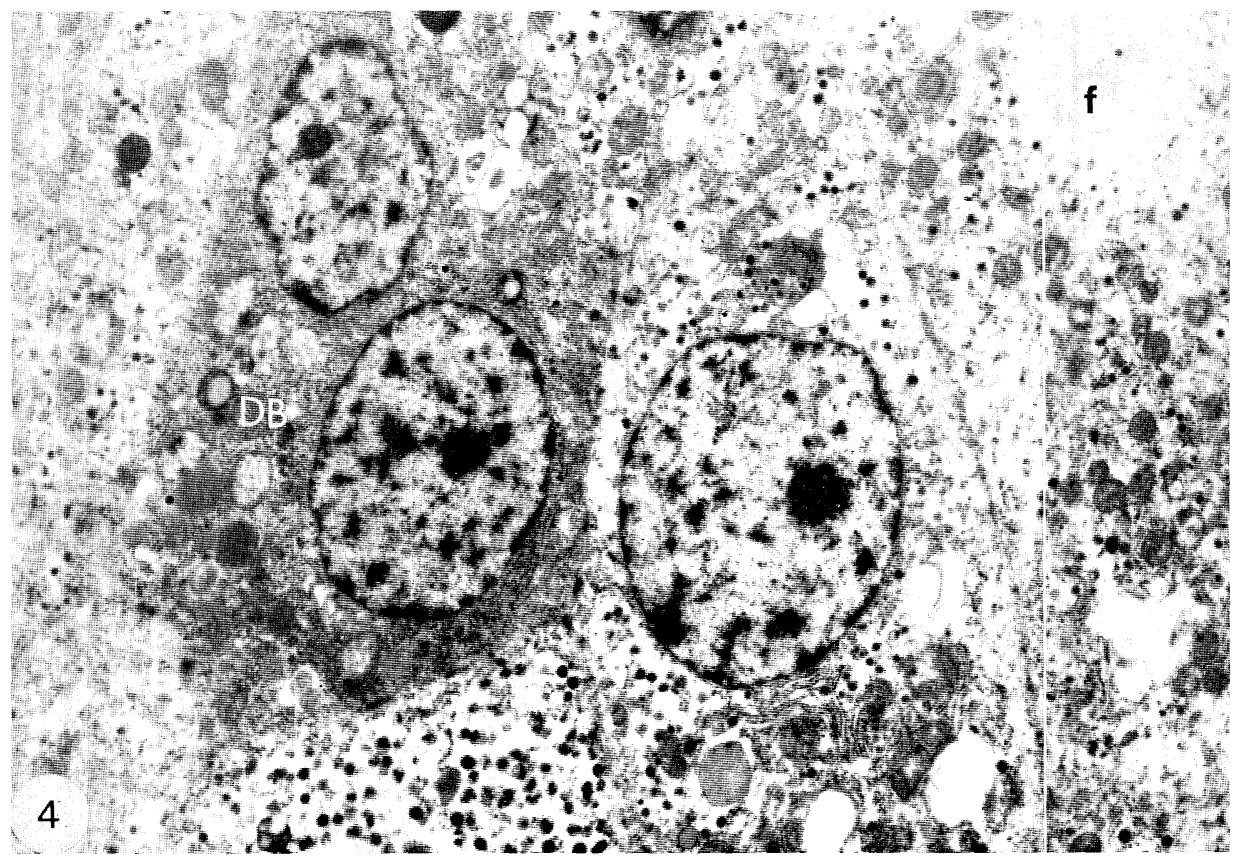

図4 明調および暗調の腺腫細胞. $\times 4,000$.

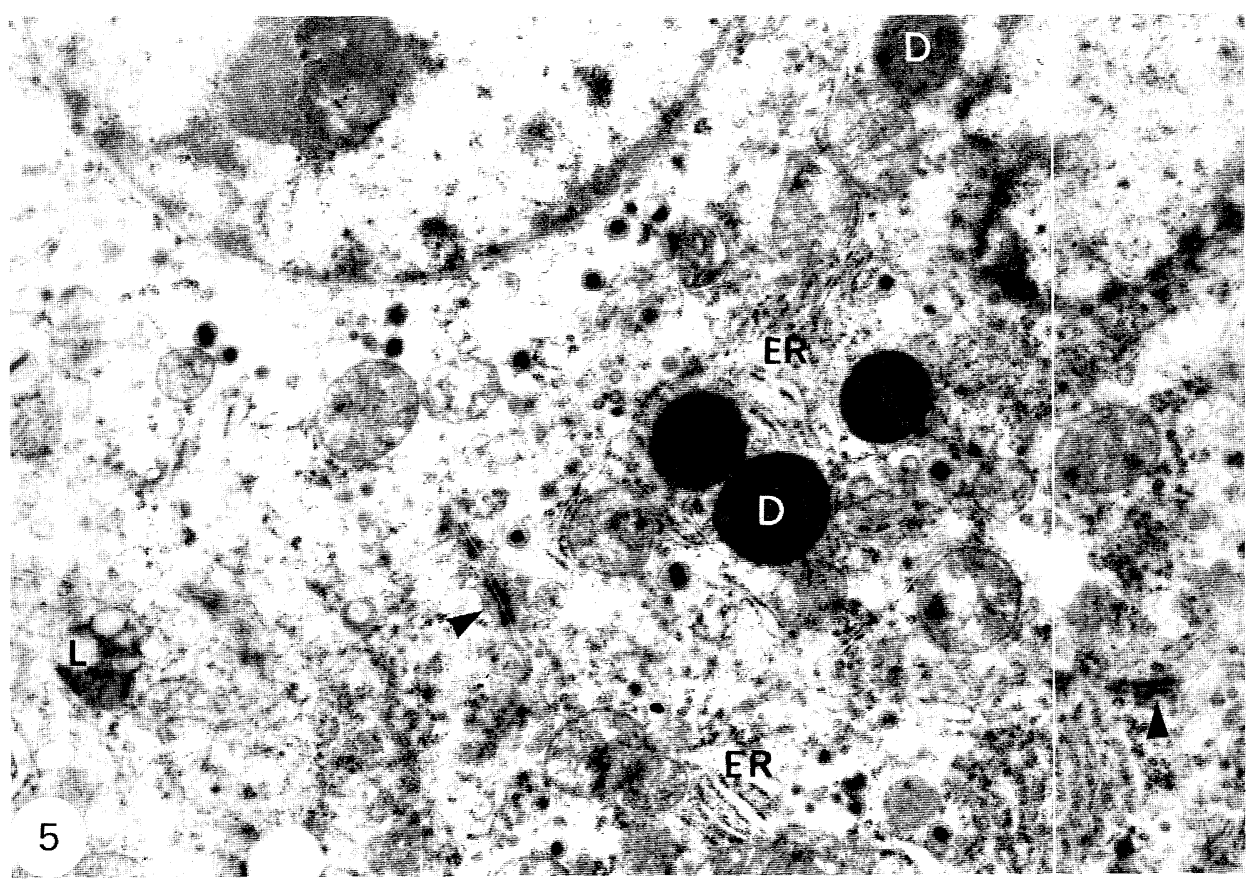

図 5 腫瘍細胞間には，接着斑がみられる（〉). × 10,000。 


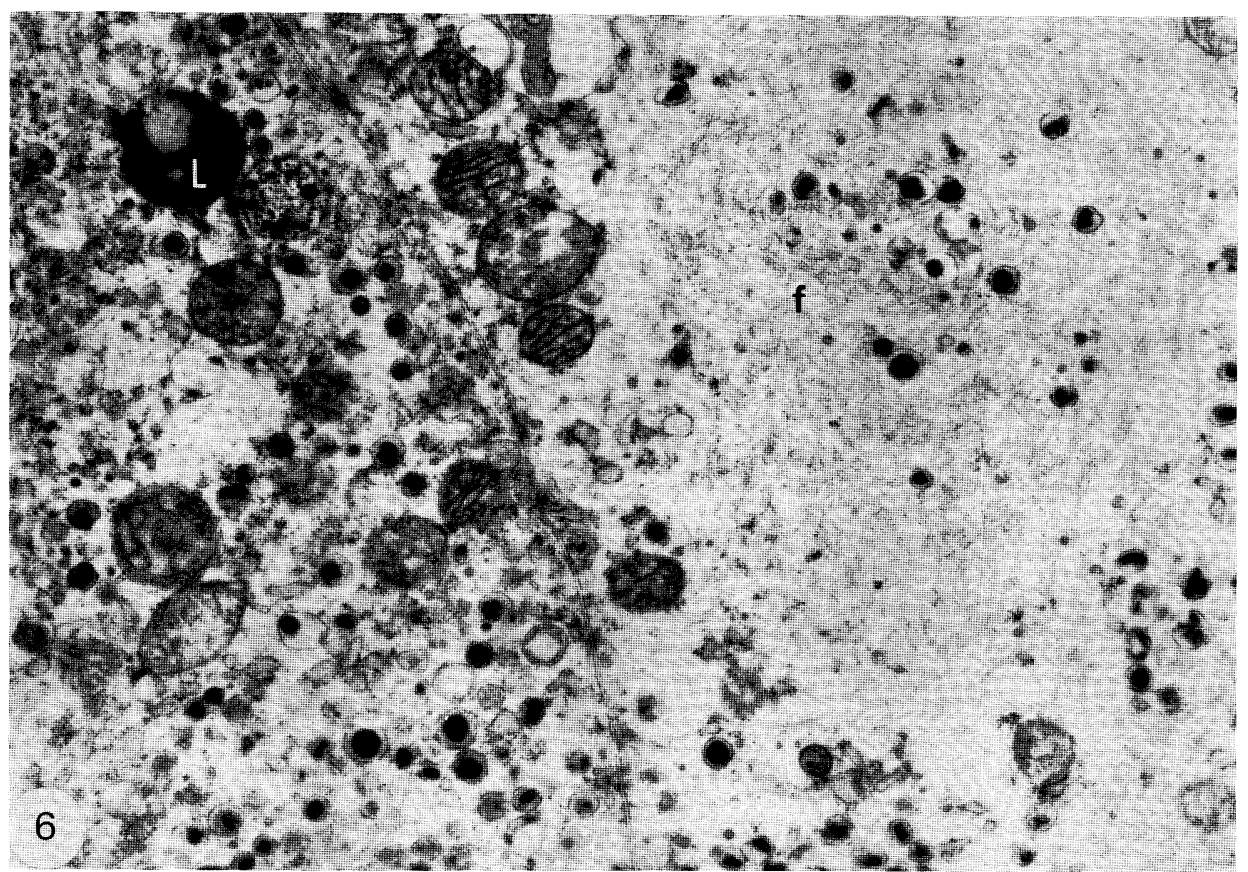

図6 細胞質内 filament と $\beta$-顆粒。 $\times 10,000$.

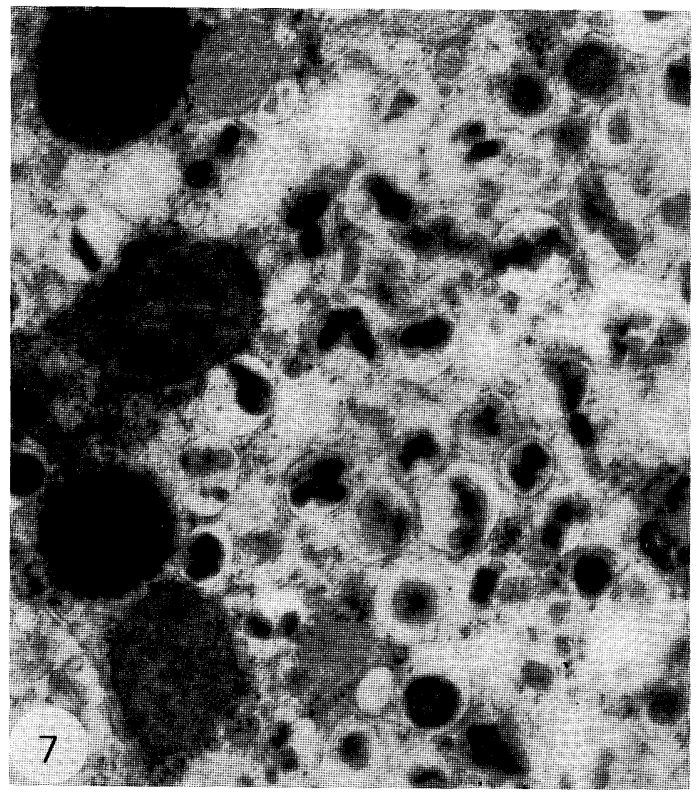

図7腺腫細胞の分泌顆粒で，さまざまな形の芯が みられる。矢印は dense body を思わせる系 粒体. $\times 8,000$.

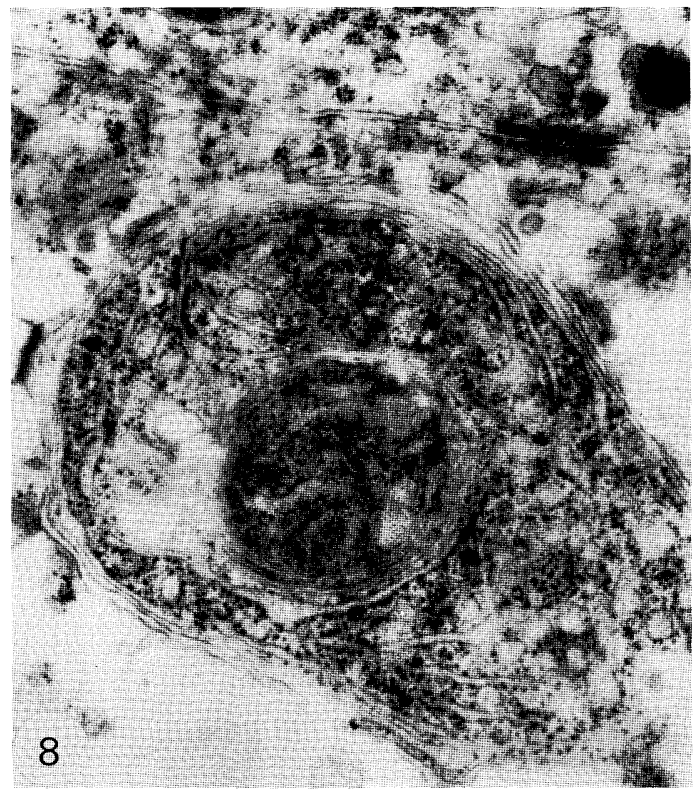

図 8 腫瘍細胞にみられた ribosome lamella complex. $\times 20,000$. 


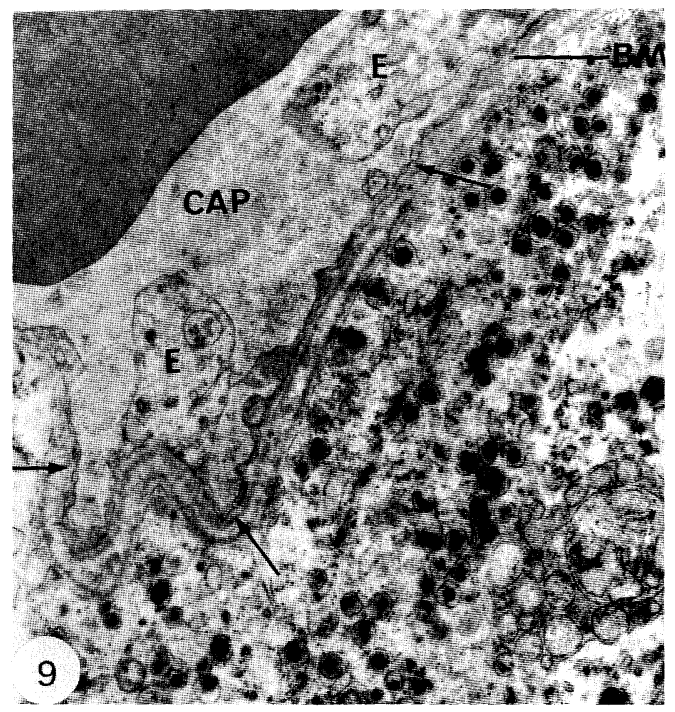

図 9 腫瘍組織内の毛細血管. 内皮細胞に fenestra がみられる。 $\times 10,000$.

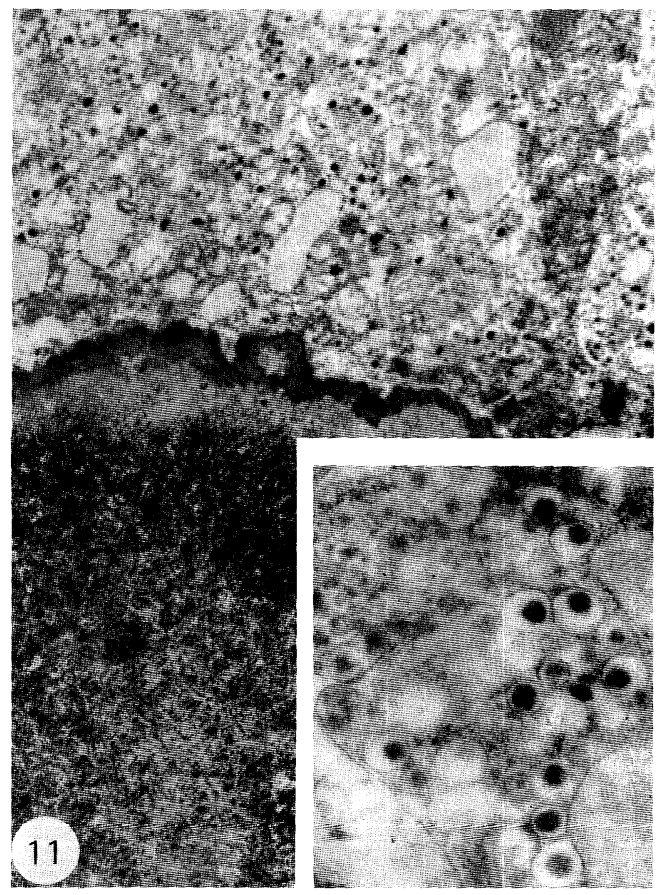

図11腺腫細胞と砂粒体. $\times 4,500$. 差込み図は $\beta$ 一顆粒で, 顆粒膜の断裂, 芯の不明瞭化などが みられる. $\times 15,000$.

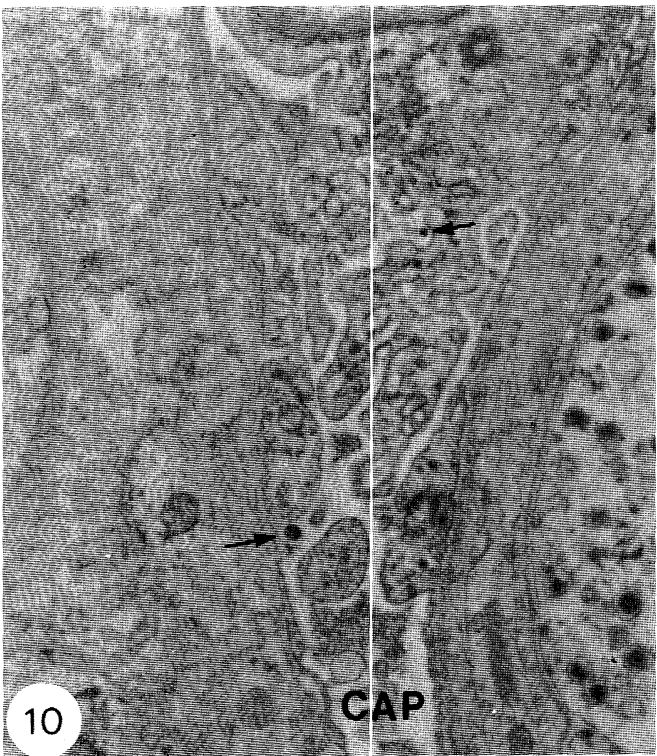

図10 毛細血管腔に分泌顆粒の芯を思わせる構造物 をみる (矢印) . ×7,500.

彩となっていた。つまり，膵舄の $\beta$ 一顆粒に酷似して いた，腫瘍細胞の分泌顆粒は: 明調および暗調細胞 ともに認められたが，正常膵島においても同様であ $る^{11)}$.

腫瘍細胞における，顆粒形或の場所に関しては， $\mathrm{rER}^{1)}$, Golgi 装置 ${ }^{1415)}$ などが桨えられている。また, 腫瘍細胞の Golgi 装置は, 正常の膵島細胞のそれよ

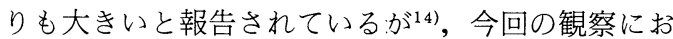
いては, 一般に Golgi 装置は, rER 同様小さかっ た。

$\beta$-顆粒の放出機序に関しては，諸説がある。すな わち，1)顆粒膜が細胞膜と融合し，顆粒の芯が基底 膜を通って血管内に放出される開口放出 (emiocytosis) ${ }^{10)}$ ，2) 顆粒の core が溶解性となり，顆粒の 限界膜を通り，さらには細胞質を通って細胞外に放 出される滲出放出 (diacrine release) ${ }^{11)}$, 腫瘍細胞が 崩壊した際に生ずる全分泌 (holocrine secretion) $)^{5)}$ などである．今回の観察では。毛細血管の基底膜に 面した腺腫細胞には，分泌顆粒が膜に接して，ある いは集簇してみられたが， erniocytosisを積極的に 支持する所見は得られなかった。しかし，毛細血管 内腔に, 分泌顆粒を思わせる高電子密度の物質が存 在したことは，あるいは開口放出の結果かもしれな 
い.さらに，分泌顆粒に芯の電子密度の低下と顆粒 膜の破壊がみられたことは， diacrine secretion を も示唆する ${ }^{11)}$. 要するに, 腫瑒細胞の $\beta$-顆粒は, 開 口放出と滲出放出のいずれによっても分泌され得る と考えたい.

Lipoidal body やdense body などは, 正常膵島細 胞においても知られている ${ }^{11)}$.今回の観察では, 腫瘍 細胞に fine fillament ${ }^{4)}$ はみられたが， cilia ${ }^{4)}$ Reinke の結晶様構造物 ${ }^{16)}$ は証明できなかった。ま た, 腫瘍組織に amyloid $^{2)}$ の沈着も認められなかっ た.

一部の腫瘍細胞に, ribosome lamella complex が観察されたが，insulinomaにおいては，PerezAtuyde (1982) ${ }^{17)}$ の報告が唯一のものである.本構造 の意義に関しては，不明であるが，過剰に産生され る insulinの合成に関与している可能性も否定はで きない.

\section{ま と め}

1. 膵島の機能性 $\beta$-細胞腺腫 (functioning $\beta$ -cell adenoma) の手術例 (50歳，女性）と剖検例 (56 歳, 女性）の 2 症例を, 光顕および電顕的に観察し た。

2. 腫瘍細胞には, 明調および暗調細胞がみられ, 両者共に分泌顆粒をもち，その芯 (core) には，さま ざまな形が認められた。芯は，原則的には crystalloid で, 正常脺島細胞の $\beta$-顆粒に酷似していた。

3. 腫瘍細胞には, rER や Golgi 装置のほか, dense body, 細胞質内 filament, lipoidal body など がみられたが，1例には ribosome lamella complex も認められた。

4. 分泌顆粒の放出には, 開口分泌 (emiocytosis) と滲出放出 (diacrine secretion) の両者が考えられ た.

当病院の青木孝直博士と倉重秀雄医学士には, 臨床経 過を, 群馬大学病理学教室の石田陽一教授には, 脳の病 理組織学的診断を教えていただいた。先生方に深謝いた します。

\section{文献}

1) Lacy, P.E., and Williamson, J.R., : Electron microscopy of Langerhans. Diabetes, $11: 509$ 513, 1962.
2) Porta, E.A., Yelly, R., et al. : Amyloidosis of functioning islet cell adenomas of the pancreas. Amer. J. Path., 41 :623-631, 1962.

3) Bencosme, S.A., Aleen, R.A., et al. : Functioning pancreatic islet cell tumors studied electron microscopically. Amer. J. Path., 42 : 1-21, 1963.

4) Greider, M. and Elliott, D.W.: Electron microscopy of human pancreatic tumors of islet cell origin. Amer. J. Path., $44: 663-678$, 1964.

5) Honjin, R., Takahashi, A., et al.: Electron microscopy of a insulinoma. J. Electron Microsc., 14 : 183-188, 1965.

6) Like, A.A.: The ultrastructure of the secretory cells of the islets of Langerhans in man. Lab. Invest., 16 : 937-951, 1967.

7）小玉孝郎, 他： Insulinoma 細胞の電子顕微鏡 的研究一とくに同一人の正常 $氏$ 氏島 $\beta$-細胞と の比較について一内科, $22 ： 1510-1514,1968$.

8) Suzuki, H. and Matsuyama, M. : Ultrastructure of functioning beta cell tumors of the pancreatic islets. Cancer, $28: 1302-1313$, 1971.

9) Rawlinson, D.G. and Christiansen, R.O.: Light and electron microscopic observations on congenital insulinoma. Cancer, $32: 1470$ 1476, 1973.

10) Yokoh, S., Iizuka, M., et al. : Electron microscopy of human pancreatic islet. Arch. hist. jap, $17:$ 429-435, 1959.

11) Shibasaki, S. and Ito, T. : Electron microscopic study on the human pancreatic islets. Arch. hist, jap., 31 : 119-154, 1969.

12）沖中重雄,他：ラ氏島腫瘍と過インスリン症, 最新医学, $16: 967-989,1961$.

13）土屋雅春, 他： 活動性ラ氏腫瘍の一例, 最新 医学, $23: 390-403 ， 1968$.

14) Nakayama, I., Takahara, O., et al. : An ultrastructural study of synthesis and release of beta granules in the human pancreas. Acta Path. Jap., $21: 329-347,1971$.

15) Kawanishi, H., Akazawa, Y., et al. : Islets of Langerhans in normal and diabetic 
humans-Ultrastructure and histochemistry, with special reference to hyalinosis. Acta Path. Jap., 16 : 177-197, 1966.

16) Mori, H., Kawai, T., et al.: Crystalline structures in human pancreatic beta cell adenoma. Acta Path. Jpn., 28 : 471-479, 1978.

17) Perez-Atayde, A.R., Hartmann, A.S., et al. : Ribosome lamella complex in a symptomatic insulinoma. Arch. Path. Lab. Med., 106 : 221223, 1982.

\title{
LIGHT AND ELECTRON MICROSCOPIC OBSERVATIONS OF FUNCTIONING BETA-CELL ADENOMA OF THE PANCREATIC ISLETS
}

\section{MASAYASU KOJIMAHARA}

\author{
Department of Pathology, Takeda General Hospital, \\ Aizuwakamatsu 965 \\ (Director: Dr. Y. Kikuchi)
}

\section{Summary}

Specimens were obstained from two patients with functioning islet cell tumors. A pancreatic tumor believed responsible for episode of hypoglycemia was removed from a 50-year-old woman (tumor : $1 \mathrm{~cm}$ in diameter in the tail) and an autopsy material was obtained from a 56 -year-old woman (tumor : $2 \times 1.2 \times 1 \mathrm{~cm}$ nodule in the tail). Microscopically, both of the tumors showed mixed patterns of cellular structure. The islets of Langerhans in the remaining pancreas appeared normal in number and histology. Histopathological examinations of the brain tissue from the autopsy case revealed a hypoxic encephalopathy due to hypoglycemia.

Electron microscopically, almost all the tumor cells contained numerous beta-granules composed of varied shaped crystalloid components. These cores of the granules were bounded by a single membrane, and their general appearance indicated their beta-cell origin. The tumor cells had also rough endoplasmic reticulum, Golgi complex, dense bodies, lipoidal bodies, and cytoplasmic filaments.

Some of the secretory granules were infrequently found in the capillary lumina. Decrease of the core density and disappearance of their membranes of the secretory granules were also noticed in the tumor cells. Therefore, insulin secretion by beta-cells in tumors is sugges:ed to release by emiocytosis and/or diacrine secretion.

No metastasis was found in two cases.

Key words: Functioning beta-cell adenoma, Electron microscopy, Beta-granule. 